\title{
Strictosidine Synthase Coding Gene Expression towards Quinine Biosynthesis and Accumulation: Inconsistency in Cultured Cells and Fresh Tissues of Cinchona ledgeriana
}

\author{
Diah Ratnadewi ${ }^{1 *}$, Miftahul Huda Fendiyanto ${ }^{2}$, Rizky Dwi Satrio ${ }^{2}$, Miftahudin Miftahudin ${ }^{1}$ and Ainna Noor Laily ${ }^{3}$ \\ ${ }^{1}$ Department of Biology, Faculty of Mathematics and Natural Sciences, Bogor Agricultural University, Bogor, Indonesia \\ ${ }^{2}$ Department of Biology, Faculty of Military Mathematics and Natural Sciences, Universitas Pertahanan, Sentul-Bogor, Indonesia \\ ${ }^{3}$ Biology Undergraduate Program, Department of Biology, Faculty of Mathematics and Natural Sciences, Bogor Agricultural \\ University, Bogor, Indonesia
}

*For correspondence: dratnadewi@apps.ipb.ac.id; diahbiologi.ipb@gmail.com

Received 26 January 2021; Accepted 17 April 2021; Published 10 June 2021

\begin{abstract}
Strictosidine synthase, encoded by the gene $S T R$, facilitates the regeneration of strictosidine, a critical intermediate for the synthesis of many plant alkaloids. The gene has, however, never been studied in Cinchona spp. The plants produce quinine alkaloid used for malaria medication, SARS-CoV-2 treatment and other industrial purposes. Cultured cells can produce the alkaloid but only at a much lower yield than the natural tree. This study describes STR expression and quinine content in various plant materials. Bioinformatic analyses were conducted on nine species of Rubiaceae to obtain reference sequences to design conservative primers for Cinchona ledgeriana STR (ClSTR). ClSTR expression was analyzed using qRT-PCR and quinine content was determined using HPLC. A complete coding sequence (CDS) of ClSTR was deposited in NCBI GenBank under the accession number MK422544.1. ClSTR was expressed in cultured cells, young and mature leaves, and stem bark. The elicited cells have higher expression than the control and they performed since the fourth week. However, the quinine content was greater in older cells. The gene expression in young leaves was superior, but quinine was most abundant in the stem bark. Every cell of $C$. ledgeriana, in culture or in the plant, expressed ClSTR and was capable of synthesizing the alkaloid quinine. The alkaloid from the leaves of the plant might be translocated and accumulated in the bark. No efflux of alkaloids from the confined cultured cells might contribute in triggering feedback inhibition in the biosynthetic pathway. This study revealed a critical obstacle in cell culture as a means of secondary metabolites production that needs further development of metabolic engineering. (C) 2021 Friends Science Publishers
\end{abstract}

Keywords: Alkaloid; Cultured cells; Intercellular translocation; STR expression; Quina plant

\section{Introduction}

Cinchona or quina plants produce quinoline alkaloids, such as quinine, one of the potential candidate molecules for SARS-CoV-2 treatment (Grosse et al. 2020; Lestari et al. 2020). Plants produce secondary metabolites (SMs) to serve a wide range of biological activities, including physiological adaptation to various environmental conditions. The type and concentration of SMs in plants depend on the species (Nair 2010), its physiology and developmental stage, and the environmental factors during their growth (Ramakrishna and Ravishankar 2011; Maldonado et al. 2017; Isah 2019). Changes in environmental factors can also lead to alteration of the composition and concentration of SMs. Naturally, SM production is very low because of their role in the host plant as signaling agents or of their direct functionality as chemical protection against predators or invasive microorganisms (Ramakrishna and Ravishankar 2011; Ncube and Staden 2015).

The biosynthetic pathway of SM production may occur in different organelles within a cell, in multiple tissues within an organ, or in various organs (Rischer et al. 2006; Zhou et al. 2010; Shitan 2016). Furthermore, SMs are transported from their source to a sink for storage, which may be unique in different plant species. Excessive amounts of SMs can toxify the producing cells (Sirikantaramas et al. 2008; Wink 2010; Shitan 2016); therefore, SMs are generally transported and stored in particular compartments, such as the vacuoles, endoplasmic reticulum and secretory vesicles, or are simply excreted into the apoplast (Yazaki 2005; Pratiwi et al. 2020). Transporting the SMs to some other organelles or organs away from where the biosynthesis occurs and accumulating them therein suggest a mechanism of self-tolerance (Sirikantaramas et al. 2008;

To cite this paper: Ratnadewi D, MH Fendiyanto, RD Satrio, M Miftahudin, AN Laily (2021). Strictosidine synthase coding gene expression towards quinine biosynthesis and accumulation: inconsistency in cultured cells and fresh tissues of Cinchona ledgeriana. Intl J Agric Biol 26:131-138 
Ramakrishna and Ravishankar 2011; Shitan 2016). Previous research has reported high variation in quinine content in cell suspension cultures, making large-scale production difficult and very expensive. There is a large discrepancy between the quinine content in cultured cells and plant tissues of Cinchona spp., in the range of 0.009 to $0.66 \%$ in C. ledgeriana cell cultures (Ratnadewi and Sumaryono 2010; Pratiwi et al. 2018; Hasibuan et al. 2021) compared with 4.8 to $9 \%$ in the plant stem bark (McCalley 2002; Kurian and Sankar 2007). It is questionable whether the low percentage of quinine in cultured cells is due to low capacity of biosynthesis or some self-tolerance mechanism.

Strictosidine is the main product of tryptophan and secologanin catalyzed by strictosidine synthases (STRs). Strictosidine becomes a critical intermediate for the synthesis of various terpenoid indole alkaloids, such as ajmalicine, vinblastine, vincristine and quinoline (Ratnadewi 2017). Depending on the plant species, many enzymes take part in this biosynthetic pathway by which specific alkaloids are produced. We focused on the STR gene, as it has a clear correlation with quinine and general quinoline alkaloid biosynthesis. The expression of this gene drives STR enzyme synthesis that would further activate the pathway toward the end product of cinchona alkaloids. By comparing the STR gene transcription and quinine content in cultured cells and fresh plant tissues, we sought to determine the source of the observed discrepancy.

Since we did not find any reference for the STR gene of Cinchona species, it was likely that this gene had never been sequenced before. Therefore, we performed bioinformatic analysis to determine the conserved regions within the coding sequence (CDS) of the STR gene in the order Gentianales, especially in the family Rubiaceae or subfamily Cinchonoideae. The results were used as references to design conservative primers for STR in C. ledgeriana. Phylogenetic trees were also generated for accessions of the Gentianales clade and the Rubiaceae family.

Aerts et al. (1991) investigated the localization of cinchona alkaloid biosynthesis by studying the distribution and activity of STR enzymes in diverse plant parts of sixmonth-old $C$. ledgeriana. Based on the enzyme activity, they reported that young organs were the sites of biosynthesis and accumulation of cinchona alkaloids. Our research aimed to study the correlation between the relative expression of the STR gene (namely, ClSTR) and alkaloid content, represented by quinine, in various fresh plant tissues and cultured cells of $C$. ledgeriana. The results of this study may be used to overcome current obstacles to improving the quinine content of $C$. ledgeriana cell culture through genetic and/or metabolic engineering in the future.

\section{Materials and Methods}

\section{Plant materials}

The friable callus used in this experiment was obtained from
Pratiwi et al. (2018) and the cell suspension culture was performed following their procedure. Young (YL) and mature leaves (ML), as well as stem bark (SB), were collected from a mature $C$. ledgeriana tree belonging to the State Plantation of PTPN VIII, Gunung Mas, West Java, Indonesia.

\section{Cell suspension culture and treatments}

Only several cell treatments were taken from those conducted by Pratiwi et al. (2018), notably those which produced the highest quinine content, highest total quinine, and control cells. A3K refers to the treatment with ABA (3 $\left.\mathrm{mg} \cdot \mathrm{L}^{-1}\right)$ and the standard amount of sucrose $\left(30 \mathrm{~g} \cdot \mathrm{L}^{-1}\right)$, while A3S denotes the treatment with ABA $\left(3 \mathrm{mg} \cdot \mathrm{L}^{-1}\right)$, sorbitol $\left(5.3 \mathrm{~g} \cdot \mathrm{L}^{-1}\right)$ and sucrose $\left(20 \mathrm{~g} \cdot \mathrm{L}^{-1}\right)$. The molarity of $5.3 \mathrm{~g} \cdot \mathrm{L}^{-1}$ sorbitol is equivalent to that of $10 \mathrm{~g} \cdot \mathrm{L}^{-1}$ sucrose. "Control" means that the culture media consisted of only the basic composition, without any elicitor or sucrose substitution. Each treatment was replicated 10 times; the cell suspension cultures were maintained for 4 and 7 weeks. After harvest, the cells were prepared for extraction and subsequent HPLC analysis.

\section{Extraction and quinine content determination}

Extraction was performed according to the method described by Hasibuan et al. (2021). The dried extract was made up to $2 \mathrm{~mL}$ with $100 \%$ methanol (HPLC grade) and a $15 \mu \mathrm{L}$ aliquot was injected into the HPLC column at $30^{\circ} \mathrm{C}$. A Hypersil ODS-2 C18 column $(250 \times 4.6 \mathrm{~mm}, 5 \mu \mathrm{m}$ particle size; Thermo Fischer Scientific, USA) was used for the HPLC (Shimadzu 10 A VP, Kyoto, Japan). The HPLC eluent consisted of sodium acetate $\left(6 \mathrm{~g} \cdot \mathrm{L}^{-1}\right)$ : acetic acid (glacial): methanol (100:1:100). The flow rate was 0.1 $\mathrm{mL} \cdot \mathrm{min}^{-1}$. The eluate from the column was monitored through a UV-vis detector at $240 \mathrm{~nm}$. Quinine sulfate CRS (EDQM-DEQM, Germany) was used as a standard. The experiment was performed in three replicates for each treatment.

\section{Bioinformatic analysis of $C l S T R$ and primer design}

We performed bioinformatic analysis to determine the conserved regions of the CDS of the STR gene in the group Gentianales, especially the family Rubiaceae or subfamily Cinchonoideae. The CDS accessions of STR analyzed were of Mitragyna speciosa (HM543187.1), Ophiorrhiza japonica (EU670747.1), O. pumila (AB060341.1), Gelsemium sempervirens (MF401945.1), Rauvolfia verticillata (DQ87216), R. serpentina (X62334.1), Tabernaemontana elegans (JN644947.1), Catharanthus roseus (X53602.1) and Vinca minor (JN644948.1) (NCBI Database). We then designed conservative primers of these STR genes using the primers application in U-Gene (Okonechnikov et al. 2012) to be employed in $C$. ledgeriana. In addition to designing the 
primers, we generated phylogenetic trees by incorporating accessions of the Gentianales clade, including X61932, Y00756, DQ872163, DQ017054, JX118639, HM543187, EU288197, JF412823, EU670747, AB060341, MF401945, FD661083, GT020720, GT664657, FD660801, FJ004233, AF329450, MK422544, KM524258, AY027510, AF084972, AF084971, FJ004235, FJ004234, AF283506, JN226128, JN644947, JN644948 and X53602 (NCBI Database). We also made a phylogenetic tree based on the family Rubiaceae accessions EU670747, GT020720, GT664657, MK422544, EU288197, HM543187, JF412823 and AB060341 to understand the evolutionary status of the ClSTR.

\section{Isolation of total RNA}

RNA isolation was performed using the RNeasy Plant Mini Kit (Qiagen, Germany). We used $100 \mathrm{mg}$ of the cultured cells, fresh portions of young leaves (YL), ML and SB of Cinchona ledgeriana. The quantity of RNA was measured using GenQuant (Bio-Rad, California, USA) and quality was visualized using agarose gel electrophoresis following the procedure described by Satrio et al. (2019).

\section{cDNA synthesis}

cDNA was synthesized using the RevertAid First Strand cDNA Synthesis Kit (\# K1622, Thermo Fisher Scientific, USA) with slight modification, as described by Satrio et al. (2019). Total RNA (5 $\mu \mathrm{g}$ ) were treated with DNase I and then mixed with $1 \mu \mathrm{L}$ oligo-dT primer $(20 \mathrm{pmol})$. The mixture was then added to $4 \mu \mathrm{L} 5 \mathrm{X}$ reaction buffer, $1 \mu \mathrm{L}$ Ribolock RNase Inhibitor $\left(20 \mathrm{U} \cdot \mu \mathrm{L}^{-1}\right), 2 \mu \mathrm{L} 10 \mathrm{~m} M$ dNTP Mix and $1 \mu \mathrm{L}$ RevertAid M-MuLV reverse transcriptase $\left(200 \mathrm{U} \cdot \mu \mathrm{L}^{-1}\right)$. The total reaction volume was $20 \mu \mathrm{L}$. All the reactions were mixed and centrifuged twice. The mixture was then incubated for $60 \mathrm{~min}$ at $42^{\circ} \mathrm{C}$ and the reaction was terminated by heating at $70^{\circ} \mathrm{C}$ for $5 \mathrm{~min}$. The concentration and purity of cDNA obtained were measured using a NanoDrop. The cDNA concentration was diluted to 50 ng. $\mu \mathrm{L}^{-1}$ before storage.

\section{ClSTR gene sequencing from Cinchona ledgeriana cell culture}

DNA was isolated following the modified CTAB method (Wahyuningtyas et al. 2016; Fendiyanto et al. 2019a), where the STR genomic regions were amplified using four forward and reverse primers (Table 1). The primers were also used to amplify STR of the previously synthesized cDNA. The amplified STR gene was identified and sequenced with an ABI PRISM 310 Genetic Analyzer machine with the Big Dye Terminator v3.1 Cycle Sequencing Kit (Applied Biosystems, USA) to obtain fulllength STR gene sequences, following the method described by Fendiyanto et al. (2019b). The sequence data were analyzed for the codon start area, CDS, and stop codon with the U-Gene program (Okonechnikov et al. 2012).

\section{ClSTR expression analysis by qRT-PCR}

Gene expression was analyzed following the procedure of Satrio et al. (2019) with a slight modification to the PCR program with respect to annealing temperature. The expression was analyzed using the primers STRl-forward: 5'-CCCCATTCTGGAACAGAAAA-3' and STR1-reverse: 5'-CCTCCTTCAGGTCCAACCAC-3', and normalized to the expression of the housekeeping gene actin (Actinforward: 5'-CCTCTTAACCCGAAGGCTAA-3' and Actinreverse: 5'-GAAGGTTGGAAAAGGACT-3'). The programs used included the following steps: $95^{\circ} \mathrm{C}$ predenaturation for $2 \mathrm{~min}, 95^{\circ} \mathrm{C}$ denaturation for $5 \mathrm{~s}, 50^{\circ} \mathrm{C}$ (for STR1) or $55^{\circ} \mathrm{C}$ (for actin) annealing for $10 \mathrm{~s}$ and $60^{\circ} \mathrm{C}$ extension for $10 \mathrm{~s}$. The qRT-PCR reaction was performed using 2x SensiFAST SYBR® High-ROX Mix (Bioline, United Kingdom) on the StepOne ${ }^{\mathrm{TM}}$ Plus Real-Time PCR System (Applied Biosystems, USA). The composition of the reaction mixture was $5 \mu \mathrm{L} 1 \mathrm{X}$ SensiFAST SYBR ${ }^{\circledR}$ High-ROX Mix, $0.4 \mu \mathrm{L}$ forward primer $(10 \mu M), 0.4 \mu \mathrm{L}$ reverse primer $(10 \mu M), 1 \mu \mathrm{L}$ cDNA template $(50 \mathrm{ng})$ and

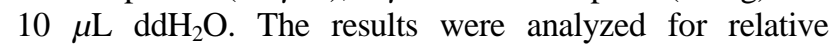
expression, following the protocols of Livak and Schmittgen (2001) and Ratnasari et al. (2016).

\section{Pearson correlation analysis}

To determine the correlation between quinine content and the STR gene expression, we performed a Pearson correlation analysis, followed by a principal component analysis (PCA). The data were analyzed in $\mathrm{R}$ program version 3.51, using corrplot mixed packages version 0.80 , as described by Lander (2014) and Fendiyanto et al. (2019b).

\section{Results}

\section{Quinine contents in cultured cells and fresh tissues}

The HPLC analysis demonstrated that both control and treated cells produced quinine (Fig. 1). The four-week-old cell culture yielded higher content of the alkaloid than the seven-week-old culture. A3S4 and A3S7 showed exceptional results; elicitation with $\mathrm{ABA}\left(3 \mathrm{mg} \cdot \mathrm{L}^{-1}\right)$ and partial substitution of sucrose with sorbitol for seven weeks (A3S7) enhanced quinine production. The SB contained a substantial amount of quinine among the organ tissues of the plant, reaching $19.83 \%$. The YL displayed twice the quinine content of the ML (Fig. 2).

\section{Bioinformatic analysis of $C l S T R$ and primer design}

Using U-Gene program to analyze nine species of the family Rubiaceae, we used the conserved area of the STR gene to design primers. We successfully synthesized four primers and determined the annealing temperature, as presented in Table 1. 
Table 1: Four primer designs resulted from bioinformatic analysis on the conserved regions of STR coding sequence in nine referent plant species

\begin{tabular}{llll}
\hline Primers & Forward Sequence $\left(5^{\prime}-3^{\prime}\right)$ & Reverse Sequence $\left(5^{\prime}-3^{\prime}\right)$ & T Annealing $\left({ }^{\circ} \mathrm{C}\right)$ \\
\hline STR1 & CCCCATTCTGGAACAGAAAA & CCTCCTTCAGGTCCAACCAC & 50 \\
STR2 & GCCGGAGTTCTTCCAATTTA & GTTGTTCTCACAAAATGCTT & 50 \\
STR3 & ATGGGTAGTTCAGAAGCCATGG & TCAGAAAGAAGAAAATTCCTTG & 55 \\
STR4 & CACACCTAACATGAACACT & TAGAAACAAAATGTTCAAGT & 55 \\
\hline
\end{tabular}

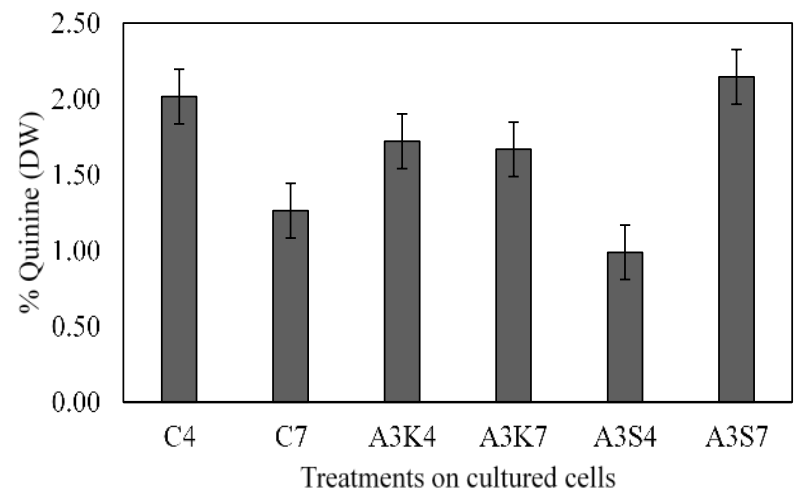

Fig. 1: Quinine content in cultured cells of Cinchona ledgeriana treated with various elicitors

The data are mean $\pm \mathrm{SD}$ of three analysis taken randomly from ten cultures per treatment. C4: 4 weeks-old control cells; C7: 7 weeks-old control cells; A3K4: cells treated with $\mathrm{ABA} 3 \mathrm{mgL}^{-1}$ and standard sucrose, 4 weeks old; $\mathrm{A} 3 \mathrm{~K} 7$ : cells treated with $\mathrm{ABA} 3 \mathrm{mgL}^{-1}$ and standard sucrose, 7 weeks old; A3S7: cells treated with $\mathrm{ABA}$ $3 \mathrm{mgL}^{-1}$, partial sorbitol, 7 weeks old: cells treated with $\mathrm{ABA} 3 \mathrm{mgL}^{-1}$, partial sorbitol, 7 weeks old

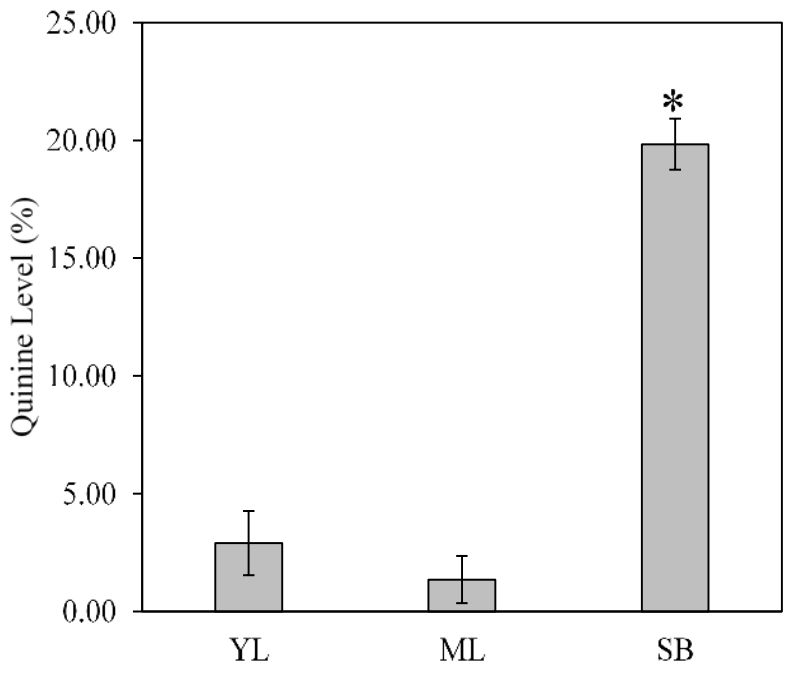

Fig. 2: Quinine contents in fresh tissues of Cinchona ledgeriana The data of quinine are mean \pm SD of three analysis. YL: young leaves; ML: mature leaves; SB: stem bark. The asterisk signs indicate statistically significant difference (Welch's t-test; $* P<0.05$ )

The cDNAs produced from the isolated total RNA of the cultured cells (concentrations ranged from 395 to 2115 $\mathrm{ng} \cdot \mathrm{mL}^{-1}$ ) were used as templates to determine the coding region of STR in C. ledgeriana. These four primers were then employed for PCR. Some full-length sequences of STR were obtained through cDNA sequencing. One consistent

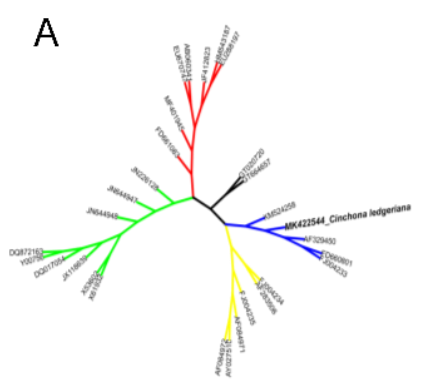

B
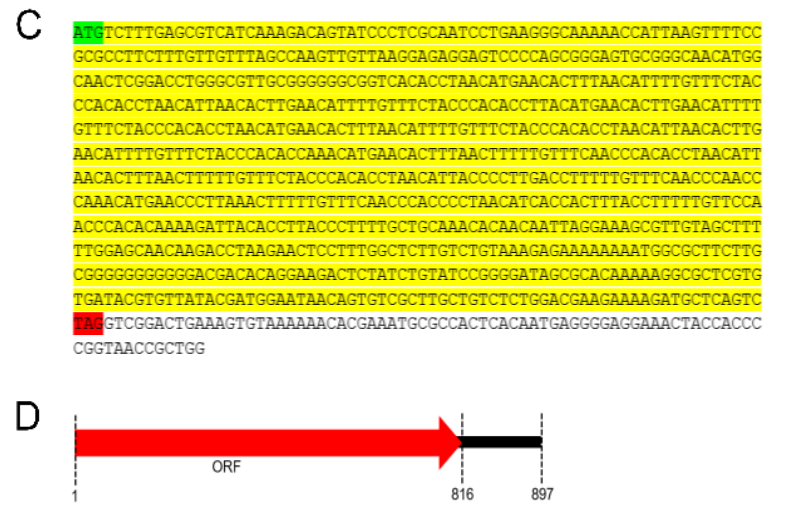

Fig. 3: Phylogenetic tree and sequence of the ClSTR in clade Genetiales and family Rubiaceae

(A) Phylogenetic tree of Cinchona ledgeriana's Strictosidine synthase (CISTR) among the clade Genetiales

(B) Phylogenetic tree of Cinchona ledgeriana's Strictosidine synthase (CISTR) among the family Rubiaceae

(C)The novel sequence of Cinchona ledgeriana's Strictosidine synthase (CISTR), 897 bp consists of ORF (open reading frame); and 3'-UTR (3'-untranslated region)

(D) Schematic structure of Cinchona ledgeriana's Strictosidine synthase (CISTR). ORF length: 1-816 bp; 3'-UTR length: 816-897 bp

result has been deposited as a complete CDS in NCBI GenBank with the accession No. MK422544.1 (https://www.ncbi.nlm.nih.gov/nuccore/MK422544.1). The gene size is $897 \mathrm{bp}$, in which the first 816-bp sequence is the open reading frame and the rest includes the 3 '-unstranslated region (Fig. 3).

Two phylogenetic trees were generated: one of the Gentianales clade and the second based on the family Rubiaceae. In the Gentianales clade, homologous sequences were divided into five groups, where the Cinchona STR gene was classified into the same group as the accessions KM524258, AF329450, FD660801 and FJ004233 (Fig. $3 A)$. In the family Rubiaceae, homologous sequences were classified into three groups, where the STR gene of Cinchona was in the same group with the accessions GT020720 and GT664657 (Fig. 3B). 


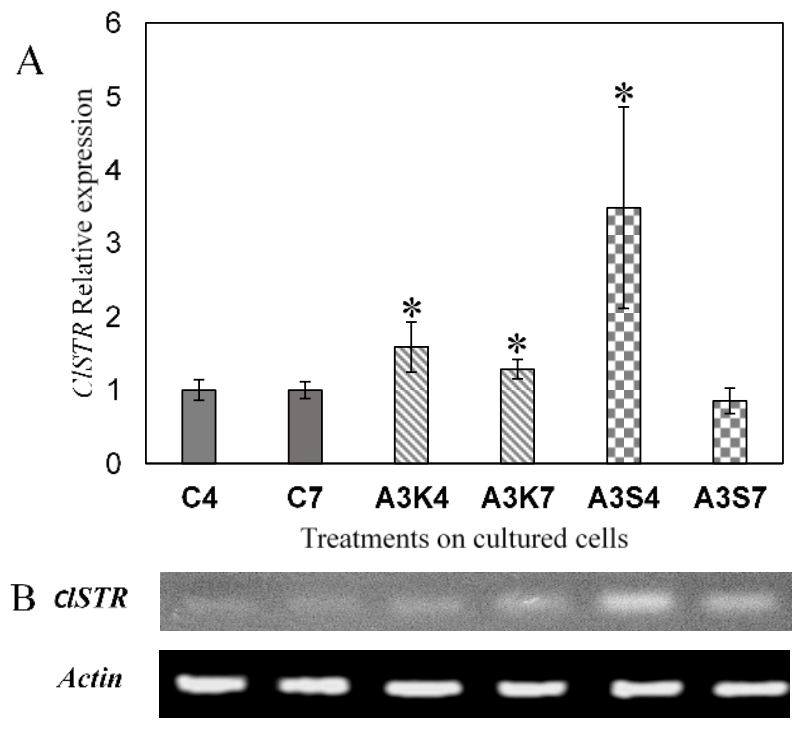

Fig. 4: The levels of ClSTR gene expression in Cinchona ledgeriana cell cultures at weeks 4 and 7 with various elicitor treatments

(A). The level of ClSTR gene expression was demonstrated by qRT-PCR method and was calculated using relative expressions following Livak and Schmittgen (2001). The data are mean \pm standard error (S.E.) of the normalized CISTR expression in the control, C4 and C7, respectively. C4: 4 weeks-old control cells; C7: 7 weeks-old control cells; A3K4: cells treated with $\mathrm{ABA} 3 \mathrm{mg} / \mathrm{L}^{-1}$ and standard sucrose, 4 weeks old; A3K7: cells treated with $\mathrm{ABA} 3 \mathrm{mg} / \mathrm{L}^{-1}$ and standard sucrose, 7 weeks old; A3S4: cells treated with $\mathrm{ABA} 3 \mathrm{mg} / \mathrm{L}^{-1}$, partial sorbitol, 4 weeks old; A3S7: cells treated with $\mathrm{ABA} 3 \mathrm{mg} / \mathrm{L}$, partial sorbitol, 7 weeks old The asterisk signs indicate statistically significant difference (Welch's t-test; $* P<0.05$ ) to $\mathrm{C} 4$.

(B). RT-PCR gel images of the ClSTR as the gene of interest and Actin as a housekeeping gene in $C$. ledgeriana cell cultures. Each experiment was repeated at least three times ( 3 biological and 3 technical repeats)

\section{ClSTR expression in cultured cells}

The suspension cultures were harvested in the fourth and seventh weeks. By taking the control cells (no elicitation) at one harvesting time as the point of reference, relative expression of ClSTR in the cultured cells was determined (Fig. 4). The gene expression in the treated cultured cells was usually higher than that in the control cells, except in the A3S7 cultured cells. The highest expression was found in A3S4 cultured cells. With elicitation treatment, it was evident that the CISTR gene was more active when the cell culture aged four weeks (A3K4 and A3S4) and its activity diminished by the seventh week (A3K7 and A3S7).

\section{CISTR expression in fresh tissues}

The level of ClSTR expression in YL was higher compared with that in ML and SB (Fig. 5). The expression level of ClSTR in the YL and SB was 1.4- and 1.1-fold higher than that in the ML, respectively.

\section{Pearson correlation analysis}

The Pearson correlation analysis indicated a significant correlation between ClSTR expression and quinine content
A

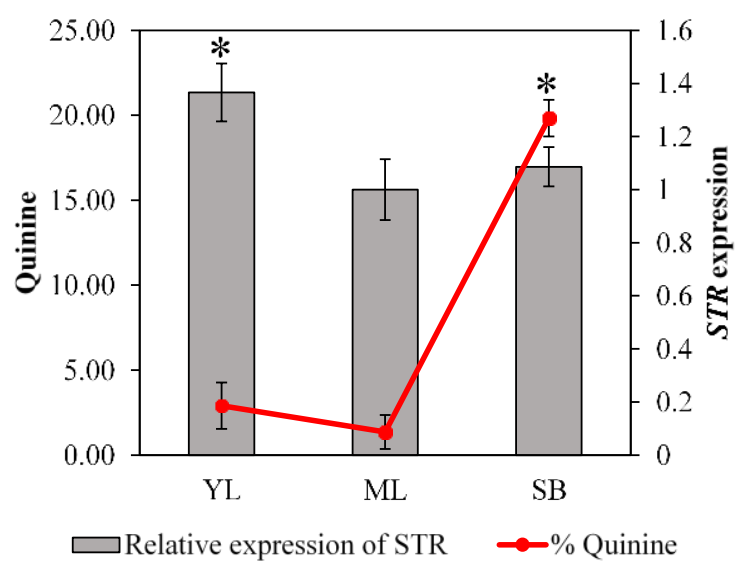

B

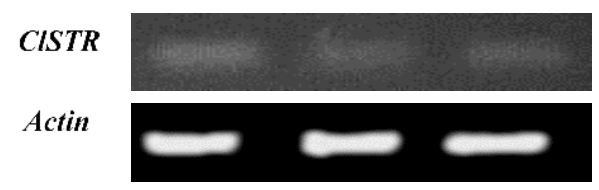

Fig. 5: The level of ClSTR gene expression is plotted with the quinine content in fresh tissues of mature plants of Cinchona ledgeriana

(A) The level of ClSTR gene expression in the fresh tissues was demonstrated by qRT-PCR method and was calculated using relative expressions following Livak and Schmittgen (2001). The quinine contents are plotted with the relative expression of STR. The data are mean \pm standard error (S.E.) of the normalized CISTR expression in ML. YL: young leaves; ML: mature leaves; SB: stem bark. The asterisk sign indicates statistically significant difference (Welch's t-test; $* P<0.05$ ) to ML

(B) RT-PCR gel images of the ClSTR as the gene of interest and Actin as a housekeeping gene, particularly in fresh tissues. Each experiment was repeated at least three times ( 3 biological and 3 technical repeats)

in Cinchona cells and fresh organ tissues (Fig. 6). It was shown that the elicited cells tended to have closer correlation with YL and ML in terms of gene expression and quinine production. The highest content of quinine given by A3S7-treated cells had only 59\% similarity with that of the SB. A PCA considers all the correlation data (Fig. 7). There are three different clusters taking both factors into consideration; one cluster contains $\mathrm{A} 3 \mathrm{~S} 4$, the second cluster consists of $\mathrm{SB}$, and the rest of the treated cells (including the control cells) and the YL and ML tissues are confined in the third cluster. According to that biplot analysis, the STR and quinine parameters are relatively similar between the cultured cells and fresh organ tissues. It also indicates that $C I S T R$ expression is tightly correlated to the quinine content.

\section{Discussion}

For years, we have tried to increase alkaloid content in cell culture of $C$. ledgeriana by applying various elicitors (Ratnadewi and Sumaryono 2010; Pratiwi et al. 2018; Hasibuan et al. 2021). The results were inconsistent from one trial to the next, despite the same treatments being applied. However, the one persistent finding was that control cells, without any elicitation, can produce alkaloids, 


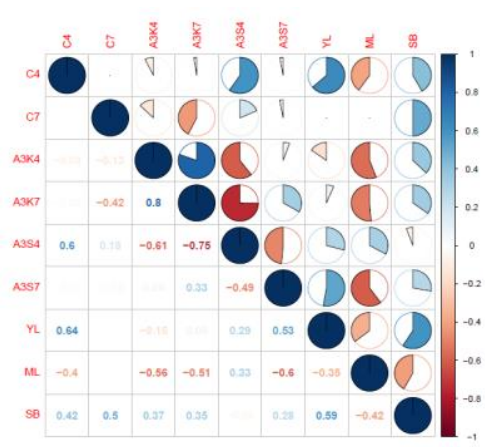

CISTR expression

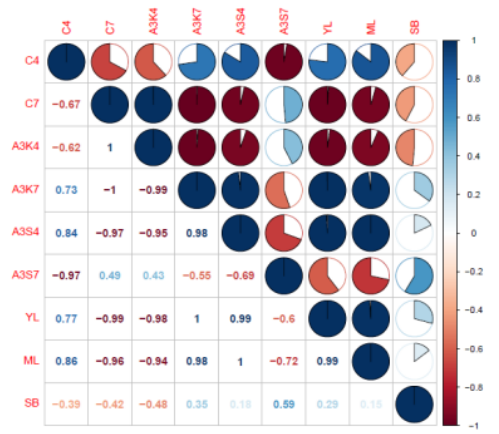

Quinine (HPLC)

Fig. 6: Pearson correlation between the treated cells and fresh tissues, based on the ClSTR gene expression and the quinine content in Cinchona ledgeriana

C4: 4 weeks-old control cells; C7: 7 weeks-old control cells; A3K4: cells treated with ABA $3 \mathrm{mgL}^{-1}$, standard sucrose, 4 weeks old; A3K7: cells treated with ABA 3 mgL ${ }^{-1}$, standard sucrose, 7 weeks old; A3S4: cells treated with ABA $3 \mathrm{mgL}^{-1}$, partial sorbitol, 4 weeks old; A3S7: cells treated with ABA 3 mgL ${ }^{-1}$, partial sorbitol, 7 weeks old; YL: young leaves; ML: mature leaves; SB: stem bark. The data were analyzed with R program 3.51 version; packages corrplot mixed 0.80 version

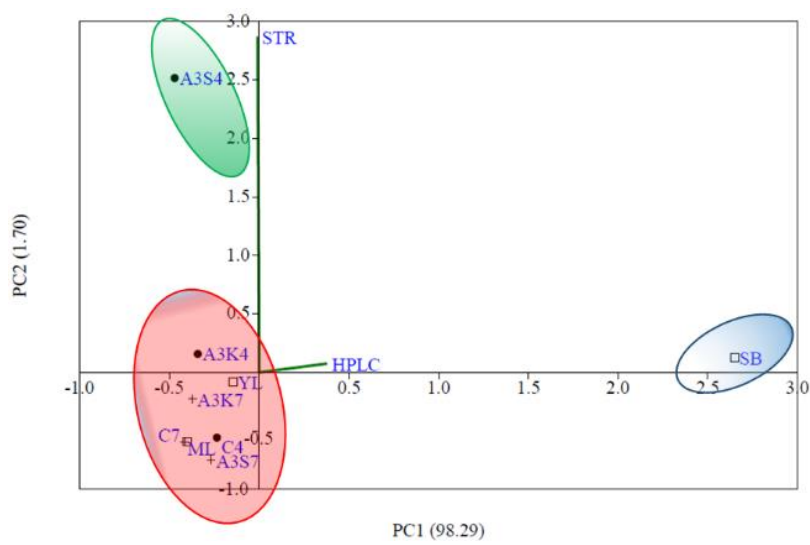

Fig. 7: Principal Component Analysis (PCA) and bi-plotting identify the cluster's performance based on the ClSTR gene expression and quinine content

C4: 4 weeks-old control cells; C7: 7 weeks-old control cells; A3K4: cells treated with ABA $3 \mathrm{mgL}^{-1}$, standard sucrose, 4 weeks old; A3K7: cells treated with ABA $3 \mathrm{mgL}^{-1}$, standard sucrose, 7 weeks old; A3S4: cells treated with $\mathrm{ABA} 3 \mathrm{mgL}^{-1}$, partial sorbitol, 4 weeks old; A3S7: cells treated with ABA $3 \mathrm{mgL}^{-1}$, partial sorbitol, 7 weeks old; YL: young leaves; ML: mature leaves; SB: stem bark; STR: Strictosidine synthase coding gene; HPLC, quinine content determined by high-performance liquid chromatography; PC1, principal component 1; PC2, principal component 2

but still a higher content found in the elicited cells. This was also reconfirmed in this research by A3S7 treatment (Fig. 1).

Strictosidine is a key intermediate and the general precursor in the biosynthesis of TIAs, including quinoline alkaloids. STR, by which strictosidine is generated from the condensation of tryptamine and secologanin, had been previously purified from cell cultures of C. robusta (Stevens et al. 1993). In addition, Aerts et al. (1991) had obtained crude extract of the enzyme from six-month-old plants of $C$. ledgeriana. For the first time here, the STR coding gene of C. ledgeriana has been sequenced.

The level of gene expression is indicative of the synthesis of the STR enzyme that leads to the alkaloid quinine biosynthesis. Quinine content increased from the fourth to the seventh week of culture when the cells were treated with double elicitors, ABA and sorbitol (A3S4 and A3S7) (Fig. 1). In contrast, the four-week-old cells exhibited higher gene expression than the older cells (Fig. 4). The YL contained twice as much as quinine as the ML, but the SB contained 6.8 times higher quinine than the YL (Fig. 2), while the YL had higher gene expression than the ML and SB (Fig. 5). Thus, the patterns of quinine content were not in agreement with $C l S T R$ gene expression in either type of plant material.

As C4 had $64 \%$ similarity with the YL, followed by $60 \%$ similarity with the A3S4 cells in terms of the STR expression (Fig. 6), it is suggested that, in the four-week-old cells, high STR transcription has occurred, similar to that in the YL. These findings indicate that STR transcription is active in all cells, regardless of the age or plant organ, but its activity in young cells and organs, i.e., four-week-old cells and YL, are generally higher than in mature cells and leaves. From the cultured cells, we know that both STR expression and alkaloid production occur in the same cell. However, the alkaloids in the cultured cells are confined to those cells as they age. No alkaloids were detected when we performed HPLC determination on the culture media (data not shown). When gene expression was diminishing in the older cells, the alkaloids (e.g., quinine) had already accumulated therein, represented by the higher quinine content, as in the case of A3S4 to A3S7.

At the plant level, YL demonstrated the highest expression of the STR gene and also exhibited moderate quinine content. On the other hand, the SB presented moderate gene expression but had very high quinine content (Fig. 5). From this, we concluded that all the organs (leaves and stem bark) express the STR gene and also produce the alkaloid. Quinine produced in the YL and ML, and most probably in the other organs too, is then translocated and stored in the SB. As a result, the SB is the richest site of the quinoline alkaloids. Similar results were found by Hotchandani et al. (2019), who worked on alkaloids in Amaryllidaceae and reported that the negative correlation 
between the gene expression level and the amount of the corresponding compounds in an organ was due to the translocation of the biosynthetic enzymes and/or the products to other parts of the plant. Pratiwi et al. (2020) reported that the alkaloids of $C$. ledgeriana were found in the idioblasts, hypodermis, and palisade of the leaves, while in the stem, they were abundantly spread over the cortex, secondary phloem, and even in the intercellular space.

Inconsistency in the production of alkaloids in cell culture may result from many factors, such as the culture age, media composition, elicitor type and length of application, culture environmental conditions, and even skill of the operators in performing the culture and extraction, up to determination. Alternatively, despite the treatment applied, the low alkaloid content in the cultured cells is probably due to the absence of other enhancing factors. From the trees of $C$. ledgeriana, Maehara et al. $(2010,2019)$ isolated and characterized several endophytic fungi that might engage in beneficial symbiosis with the host plants. Those fungi may also partially contribute to the alkaloid production of trees, which may explain why the alkaloid content in trees is substantially higher than that in cultured cells, where the culture media and in vitro environment are totally free from microorganisms.

Some SM biosynthetic pathways have been reported to be active in several different organs within a plant (Zhou et al. 2010; Dewey and Xie 2013; Shitan 2016). However, the full pathway of alkaloid biosynthesis in Cinchona plants, including the availability of the substrates and enzymes, might be present within the same cells, even in every single cell, independent of cell differentiation.

At the physiological level, alkaloids are toxic to the cells producing them if the metabolites accumulate in those same cells to an excessive concentration (Yazaki 2005; Sirikantaramas et al. 2008; Shitan 2016). Therefore, naturally, the alkaloids will not accumulate in high concentration in a closed compartment system like a cell because of feedback inhibition. In the entire plant, self-toxicity is avoided by longdistance transportation such as efflux detoxification (Yazaki 2005) to less sensitive tissues or organs, namely, accumulation sites such as intercellular spaces, cuticle, resin duct (apoplasts) (Wink 2010; Shitan et al. 2015; Shitan 2016). Ideally, membrane permeability may be loosened to facilitate the excretion of SMs from the in vitro producing cells into the culture media. Some efforts have been made to increase the continuous production of SMs in cultured cells, for instance, by the application of certain chemicals (BoitelConti et al. 2000; Zhang and Franco 2005), or by improving the activity of certain efflux carriers such as plant $\mathrm{ABC}$ transporter (Wink 2010) or AtDTX1 in Arabidopsis thaliana, which belongs to the multidrug and toxic compound extrusion family ( $\mathrm{Li}$ et al. 2002). At least four families of transporter proteins for SMs have been identified (Shitan 2016). For SMs that are entirely synthesized in the same cells, future research can be directed toward finding any technology suitable for this purpose.

\section{Conclusion}

The STR gene was expressed, and quinine biosynthesis occurred in all cells and tissues of $C$. ledgeriana under investigation. The low quinine content in the cultured cells might be due to the absence of intercellular transportation of the alkaloid that further blocks its continuous production. Cinchona alkaloid content may be increased by strengthening STR expression in conjunction with development of certain efflux carriers in the cultured cells through genetic means along with technical improvements.

\section{Acknowledgments}

We thank the Ministry of Research, Technology, and Higher Education of the Republic of Indonesia for funding this work through the second year of the PTUPT Program (grant no. 1720/IT3.11/PN/2018). We also appreciate PT Perkebunan Nusantara VIII-Gunung Mas and PT Sinkona Indonesia Lestari for providing materials.

\section{Author Contributions}

D Ratnadewi conceptualized and designed the experiment; D Ratnadewi, MH Fendiyanto, RD Satrio, and AN Laily conducted the laboratory experiments; M Miftahudin, $\mathrm{MH}$ Fendiyanto, and RD Satrio assisted with the bioinformatic analysis; and D Ratnadewi and MH Fendiyanto analyzed the data and wrote the manuscript.

\section{Conflict of Interest}

Authors declare no conflict of interest.

\section{Data Availability}

The data and supplementary material are all available online.

\section{Ethics Approval}

The research does not involve the ethical approval.

\section{References}

Aerts RJ, AD Waal, EJM Pennings, R Verpoorte (1991). The distribution of strictosidine-synthase activity and alkaloids in Cinchona plants. Planta 183:536-541

Boitel-Conti M, JC Laberche, A Lanoue, C Ducrocq, NB Sangwan (2000). Influence of feeding precursors on tropane alkaloid production during an abiotic stress in Datura innoxia transformed roots. Plant Cell Tiss Org Cult 60:131-137

Dewey RE, J Xie (2013). Molecular genetics of alkaloid biosynthesis in Nicotiana tabacum. Photochemistry 94:10-27

Fendiyanto MH, RD Satrio, S Suharsono, A Tjahjoleksono, I Hanarida, M Miftahudin (2019a). QTL for aluminum tolerance on rice chromosome 3 based on root length characters. Sabrao J Breed Genet 51:451-469 
Fendiyanto MH, RD Satrio, S Suharsono, A Tjahjoleksono, M Miftahudin (2019b). Correlation among Snpb11 markers, root growth and physiological characters of upland rice under aluminum stress. Biodiversitas 20:1243-1254

Grosse M, N Ruetalo, R Businger, S Rheber, C Setz, P Rauch, J Auth, E Brysch, M Schindler, U Schubert (2020). Evidence that quinine exhibits antiviral activity against SARS-CoV-2 infection in vitro. Available at: www.preprints.org (Accessed: 6 July 2020).

Hasibuan YA, D Ratnadewi, ZA Mas'ud (2021). Alkaloids production and cell growth of Cinchona ledgeriana Moens: Effects of fungal filtrate and methyl jasmonate elicitors. Indon J Sci Technol 6:31-40

Hotchandani T, JD Villers, I Desgagné-Penix (2019). Developmental regulation of the expression of Amaryllidaceae alkaloid biosynthetic genes in Narcissus papyraceus. Genes 10; Article 594

Isah T (2019). Stress and defence responses in plant secondary metabolites production. Biol Res 52; Article 39

Kurian A, MA Sankar (2007). Medicinal plants. In: Horticultural Science Series-2, p:374. Peter KV (Ed.). New India Publ. Agency, New Delhi, India

Lander JP (2014). $R$ for Everyone: Advanced Analytics and Graphics. Addison-Wesley Professionals, Boston, Massachusetts, USA

Lestari K, T Sitorus, Instianty, S Megantara, J Levita (2020). Molecular docking of quinine, chloroquine and hydroxychlroroquine to angiotensin converting enyme 2 (ACE2) receptor for discovering new potential COVID-19 antidote. J Adv Pharm Educ Res 10:1-4

Li L, Z He, GK Pandey, T Tsuchiya, S Luan (2002). Functional cloning and characterization of a plant efflux carrier for multidrug and heavy metal detoxification. J Biol Chem 277:5360-5368

Livak KJ, TD Schmittgen (2001). Analysis of relative gene expression data using real-time quantitative PCR and the 2(T)(-Delta Delta Ct) method. Methods 25:402-408

Maldonado C, CJ Barnes, C Cornett, E Holmfred, SH Hansen, C Persson, A Antonelli, N Rønsted (2017b). Phylogeny predicts the quantity of antimalarial alkaloids within the iconic yellow Cinchona bark (Rubiaceae: Cinchona calisaya). Front Plant Sci 8; Article 391

Maehara S, A Agusta, Y Tokunaga, H Shibuya, T Hata (2019). Endophyte composition and Cinchona alkaloid production abilities of Cinchona ledgeriana cultivated in Japan. $J$ Nat Med 73:431-438

Maehara S, P Simanjuntak, K Ohashi, H Shibuya (2010). Composition of endophytic fungi living in Cinchona ledgeriana (Rubiaceae). $J$ Nat Med 64:227-230

McCalley DV (2002). Analysis of the Cinchona alkaloids by highperformance liquid chromatography and other separation techniques. J Chromatogr A 967:1-19

Nair KP (2010). The Agronomy and Economy of Important Tree Crops of the Developing World. Elsevier, Amsterdam, The Netherlands

Ncube B, JV Staden (2015). Tilting plant metabolism for improved metabolite biosynthesis and enhanced human benefit. Molecules 20:12698-12731

Okonechnikov K, O Golosova, M Fursov (2012). Unipro U GENE: A unified bioinformatics toolkit. Bioinformatics 28:1166-1167

Pratiwi DR, YC Sulistyaningsih, D Ratnadewi (2020). Localization of alkaloid and other secondary metabolites in Cinchona ledgeriana Moens: Anatomical and histochemical studies on fresh tissues and cultured cells. Hayati J Biosci 27:1-7
Pratiwi DR, Sumaryono, PT Sari, D Ratnadewi (2018). Cinchona cells performance in in vitro culture: Quinine alkaloid production with application of different elicitors. IOP Conf Ser: Earth Environ Sci 185; Article 012029

Ramakrishna A, GA Ravishankar (2011). Influence of abiotic stress signals on secondary metabolites in plants. Plant Signal Behav 6:1720-1731

Ratnadewi D (2017). Alkaloids in plant cell cultures. In: Alkaloids. Alternatives in Synthesis, Modification and Application, pp:1-29. Georgiev V, A Pavlov (Eds.). IntechOpen, Rijeka, Croatia

Ratnadewi D, Sumaryono (2010). Quinoline alkaloids in suspension cultures of Cinchona ledgeriana treated with various substances. Hayati J Biosci 17:179-182

Ratnasari T, A Tjahjoleksono, M Miftahudin (2016). Transgene insertion stability and aluminum tolerance candidate gene expression in T3 generation of transgenic tobacco. Intl J Agric Biol 18:607-614

Rischer H, M Oresic, T Seppanen-Laakso, M Katajamaa, F Lammertyn, W Ardilles-Diaz, MCEV Montagu, D Inze, KM Oksman-Caldentey, A Goossens (2006). Gene-to-metabolites networks for terpenoid indole alkaloid biosynthesis in Catharanthus roseus cells. Proc Natl Acad Sci 103:5614-5619

Satrio RD, MH Fendiyanto, EDJ Supena, S Suharsono, M Miftahudin (2019). Identification of drought-responsive regulatory genes by hierarchical selection of expressed sequence tags and their expression under drought stress in rice. Intl J Agric Biol 22:1524-1532

Shitan N (2016). Secondary metabolites in plants: Transport and selftolerance mechanisms. Biosci Biotechnol Biochem 80:1283-1293

Shitan N, M Hayashida, K Yazaki (2015). Translocation and accumulation of nicotine via distinct spatio-temporal regulation of nicotine transporters in Nicotiana tabacum. Plant Signal Behav 10; Article e1035852

Sirikantaramas S, M Yamasaki, K Saito (2008). Mechanisms of resistance to self-produced toxic secondary metabolites in plants. Phytochem Rev 7; Article 467

Stevens LH, C Giroud, EJM Pennings, R Verpoorte (1993). Purification and characterization of strictosidine synthase from a suspension culture of Cinchona robusta. Photochemistry 33:99-106

Wahyuningtyas W, M Miftahudin, U Widyastuti, A Tjahjoleksono (2016). Construction of RNA interference vector to silence aluminum tolerance gene candidate in rice cv Hawara Bunar. Hayati J Biosci 23:79-84

Wink M (2010). Introduction: biochemistry, physiology and ecological functions of secondary metabolites. Апnи Plant Rev 40:1-19

Yazaki K (2005). Transporters of secondary metabolites. Curr Opin Plant Biol 8:301-307

Zhang W, CMM Franco (2005). Production of plant secondary metabolites using adsorption and elicitation in cell suspension culture. Patent WO 2005012507 A1. The University of Melbourne, Commonwealth Scientific And Industrial Research Organisation, Tridan Ltd., Albright \& Wilson (Australia) Ltd., The Flinders University of South Australia Available at: http://www.freepatentsonline.com/WO2005012507.pdf (Accessed: 13 July 2020)

Zhou ML, HL Hou, XM Zhu, JR Shao, YM Wu, YX Tang (2010). Molecular regulation of terpenoid indole alkaloids pathway in the medicinal plant. Catharanthus roseus. J Med Plant Res 25:2760-2772 